of the university system-the University Grants Committee and the Science Research Council between them have the instruments of selectivity and concentration in their hands. It will be best for everybody if American universities somehow devise for themselves machinery for regulating their development at a time of contraction, not growth.

Along with this it is important that the academic community should seize every opportunity to ask searching questions about the federal government's now truncated policies for research and development. Is it sensible that the National Science Foundation should be so wedded to applied research when it has yet to demonstrate that it can function as an entrepreneur of innovation more effectively than the other operating agencies of the federal government? Is it proper that so much of the spending of the National Aeronautics and Space Administration should be committed to space flights when what is spent on basic science is being reduced? In the months ahead, it is essential that academics should come out from the covers and urge these and other arguments on the federal government. If in the process they find it necessary to take Senator Edward Kennedy to task for the inconsistencies in his Science and Technology Bill, no harm will have been done.

\section{Another Pretty Flame}

A HIGH-RANKING newsman from the BBC confessed on late night television last year that the BBC's television news had lost its head over the eruption of Mount Etna. Too much time, he felt, had been devoted to films of fiery lava, not because it ranked high in social, economic or political importance, but because it was so photogenic.

Now that the Helgafell Volcano in the Westman Islands off the coast of Iceland is claiming chunks of the six, nine and ten o'clock news shows, what is really at fault with television's coverage of such events is plain for all who care about science to see. There is no attempt at all to explain why Iceland should be visited by this form of natural catastrophe so often. When there is a pseudo-science story, such as a man walking on the moon, the television makers trot out their science correspondents, import geologists and physicists and have a field day making papier mache models and diagrams. But none of this treatment is, in fact, given to a genuine scientific news event. No one would know, watching the shooting fires and floating pumice on colour television, that new understanding of the forces at work on the mid-Atlantic ridge and other plates of the earth's crust has been one of the major scientific advances in recent years.

Television is feeding the public the primitive idea that nature is random and capricious. It is doing this particularly in children's programmes. The BBC's vaunted after-school programme. "Blue Peter", has been conspicuously lazy in its approach to science. It devoted a whole segment of a show recently to the Icelandic eruption with no mention of the mid-Atlantic ridge. To fill out its time, the programme dug out old film to show that the Blue Peter team had looked lava in the face at Mount Etna too. The same programme, some days earlier, had discussed tropical fish from the point of view of their ability to harm man. Some fish stung, some bit and others (sharks) could chew people all to bits. The fact that these natural defences were of some advantage to the fish was not discussed.

There has been a voguish anti-rationalism in many television documentaries ostensibly devoted to science and technology which is worrying. For example, the recent programme on the common fear of travel by air seemed to give legitimacy to the fear, on the grounds that many people suffer from it. (Its title was "The Only Way to Go".)

Professor Velikovsky also came in for some less-thanobjective treatment from television recently. There was Velikovsky and his theories, on the one hand, and conventional astronomers and their theories on the other, and glowing sunsets suggesting worlds in collision to bind the two together. The science programme, "Horizon", has followed a doomsday line lately.

It is being said that Dr Bronowski's new series, "The Ascent of Man", will correct the anti-science swing inside the BBC. That would be good, but there still needs to be some new thinking on science news itself. There are reasons why the earth's crust bursts open where it does and why earthquakes occur in some places and not others. News editors who just show the pictures without explanation are doing as much disservice to the public as if they showed photographs of bombs and victims without mentioning that there was a war going on.

\section{Years Ago}

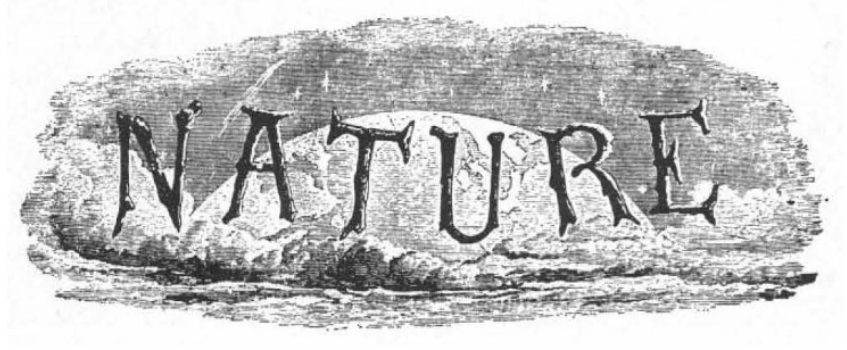

SEDGWICK

GEOLOGX has lost her veteran leader! While yet firm in intellect, full of kind and generous feeling, and occupied on the last pages of the latest record of his labours, in the ninth decad of a noble life, Sedgwick has gone to his rest. Under the shadow of this great loss we look back through more than half a century, and behold no more conspicuous figure in the front ranks of advancing geology than the strenuous master workman, the eloquent teacher, the chivalrous advocate of science, who has now finished his task. Severe illness, borne with fortitude, had gradually withdrawn him from scenes once brightened by his ever-welcome presence, but could not tame the high spirit, or cloud the genial sympathies which had won for him, more than for other men, the loving admiration of his fellows in age and followers in study. Rarely has a patriarchal life been crowned with such enduring and affectionate respect.

From Nature, 7, 257. February 6, 1873. 